\title{
DANA PIHAK KETIGA DAN PENDAPATAN PEMBIAYAAN BAGI HASIL TERHADAP LABA PADA BANK UMUM SYARIAH INDONESIA
}

\author{
NANA DIANA \\ nana.diana@fe.unsika.ac.id \\ SYAMSUL HUDA \\ syamsul.huda@fe.unsika.ac.id \\ Program Studi Akuntansi, Fakultas Ekonomi dan Bisnis \\ Universitas Singaperbangsa Karawang
}

\begin{abstract}
ABSTRAK
Perkembangan perbankan syariah di indonesia cukup signifikan, seiring dengan tanggapan masyarakat yang sangat positif yang membutuhkan suatu sistem perbankan alternatif yang selain menyediakan jasa perbankan yang sehat, juga memenuhi prinsip-prinsip syariah. Penelitian ini menggunakan metode deskriptif kuantitatif dan data yang digunakan oleh penulis dalam penelitian ini adalah data sekunder.Sumber data dalam Penelitian ini adalah Laporan Keuangan Bank Umum Syariah di Indonesia Tahun 2012-2017, sehingga data tersebut menjadi 6 tahun x 6 Bank Umum Syariah $=36$ data yang digunakan.Hasil penelitian didapatkan bahwa pengaruh positif dana pihak ketiga terhada laba sebesar 0,357 sedangkan pengaruh pengaruh pendapatan pembiayaan bagi hasil terhadap laba sebesar 0,220 memiliki pengaruh yang negatif. Hubungan secara simultan yaitu pengaruh dana pihak ketiga dan pendapatan pembiayaan bagi hasil terhadap laba pada Bank umum syariah Indonesia memiliki hubungan yang signifikan dilihat dari nilai signifikansi yang berada dibawah 0,05 yaitu sebesar 0,037 .
\end{abstract}

Kata Kunci : Perbankan, Pendapatan, dan Laba

\begin{abstract}
The development of Islamic banking in Indonesia is quite significant, along with a very positive public response that requires an alternative banking system which in addition to providing healthy banking services, also meets sharia principles. This study uses descriptive quantitative methods and the data used by the authors in this study are secondary data. The data sources in this study are Financial Statements of Islamic Commercial Banks in Indonesia in 2012-2017, so that the data becomes 6 years x 6 Sharia Commercial Banks $=36$ the data used. The results showed that the positive effect of third party funds on profit amounted to 0.357 while the effect of the effect of revenue sharing on income of 0.220 had a negative influence. Simultaneous relationships, namely the influence of third party funds and profit sharing financing income on profits in the Indonesian Islamic commercial banks have a significant relationship seen from the significance values below 0.05, which is equal to 0.037 .
\end{abstract}

Keywords: Banking, Income, and Profit 


\section{PENDAHULUAN}

Indonesia adalah Negara dengan penduduk muslim terbesar di dunia. Mayoritas yang beragama islam menjadikan indonesia sebagai pasar yang potensial dalam pengembangan keuangan syariah. Salah satu yang saat ini sudah mulai berkembang dengan pesat yaitu adalah dengan adanya bank-bank yang kegiatan operasionalnya menggunakan prinsip syariah. Perbankan syariah pada dasarnya merupakan pengembangan dari konsep ekonomi islam, terutama dalam bidang keuangan yang dikembangkan sebagai suatu respon dari kelompok ekonomi dan praktisi perbankan muslim yang berupaya mengakomodasi desakan dari berbagai pihak yang menginginkan adanya jasa transaksi keuangan yang dilaksanakan sejalan dengan nilai moral dan prinsip-prinsip syariah islam. Perkembangan perbankan syariah di indonesia cukup signifikan, seiring dengan tanggapan masyarakat yang sangat positif yang membutuhkan suatu sistem perbankan alternatif yang selain menyediakan jasa perbankan yang sehat, juga memenuhi prinsip-prinsip syariah. Perkembangan industri keuangan syariah secara informal telah dimulai sebelum dikeluarkannya kerangka hukum formal sebagai landasan operasional perbankan syariah di indonesia. Berikut grafik statistik Perkembangan Perbankan Umum Syariah di Indonesia sebagai berikut.

\section{GRAFIK 1.1}

Rata-rata Dana Pihak Ketiga Pada Bank Umum Syariah di Indonesia Periode tahun 2012-2016

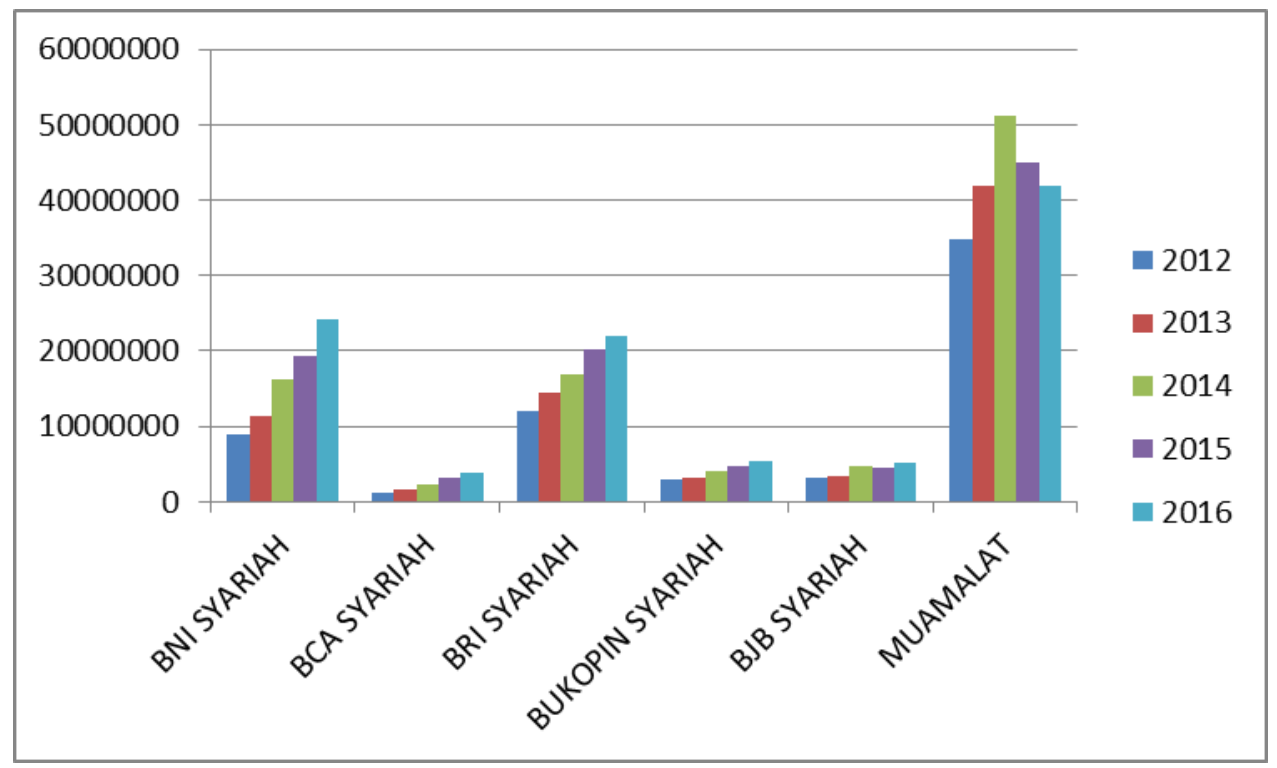

Berdasarkan grafik 1.1 diatas terlihat beberapa perbankan syariah seperti: BNI Syariah, Bank Muamalat Indonesia, dan Bukopin Syariah terlihat Dana Pihak mengalami kenaikan setiap tahunnya sedangkan pada BJB Syariah dan Bank Muamalat tahun 2015 terlihat dana pihak ketiga mengalami penurunan.

\section{GRAFIK 1.2}

Rata-rata Pendapatan Pembiayaan Bagi Hasil Pada Bank Umum Syariah di Indonesia Periode tahun 2012-2016 


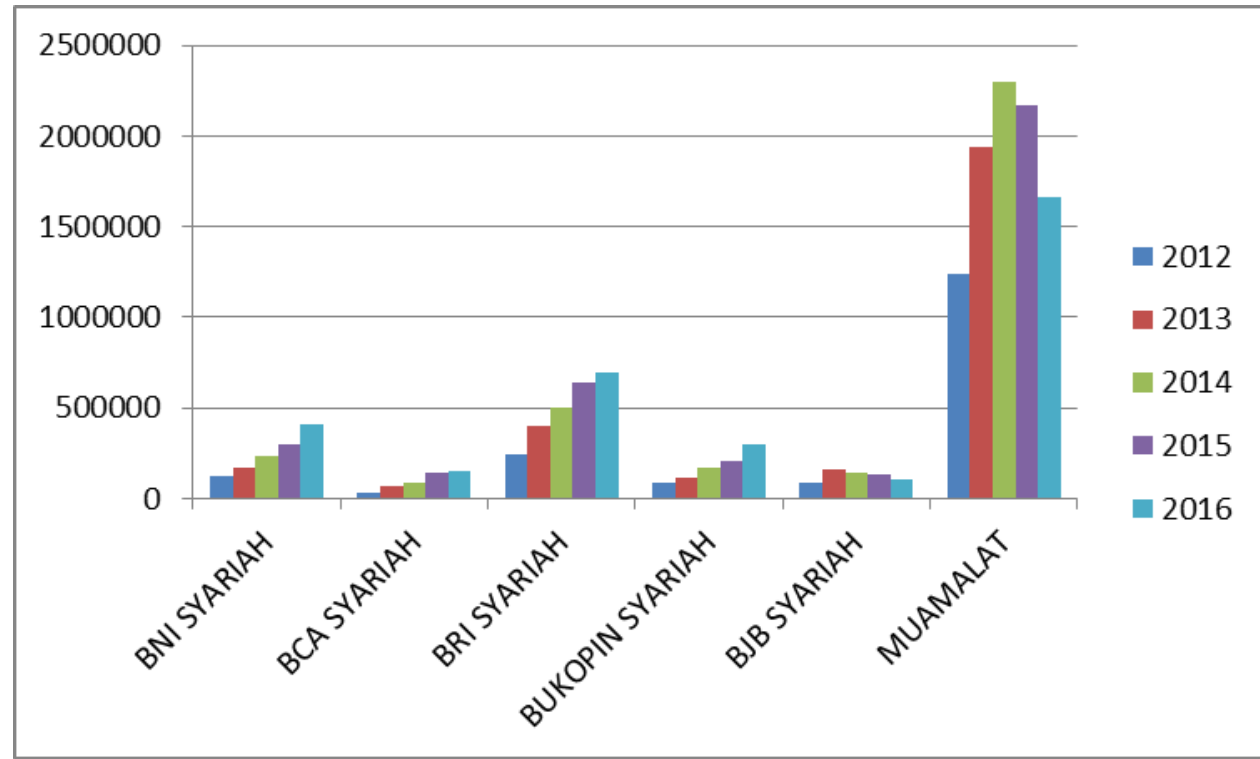

Berdasarkan grafik 1.2 diatas terlihat beberapa perbankan syariah seperti: BJB Syariah, BNI Syariah, Bank Muamalat Indonesia, dan Bukopin Syariah terlihat pendapatan pembiayaan bagi hasil terus mengalami peningkatan setiap tahunnya, sedangkan pada Bank BJB Syariah dan Bank Muamalat tahun 2015 terlihat Pendapatan Pembiayaan Bagi hasil mengalami penurunan.

GRAFIK 1.3

Rata-rata Laba Pada Bank Umum Syariah di Indonesia

Periode tahun 2012-2016

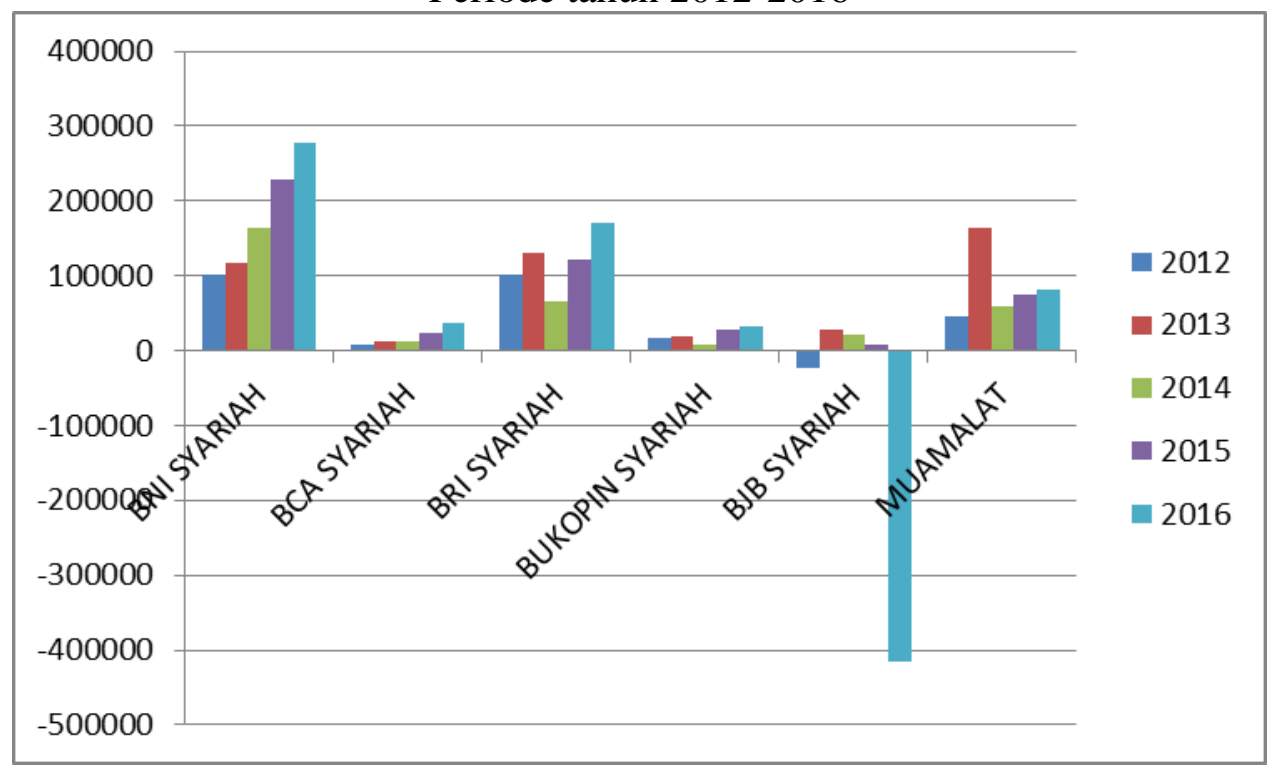

Berdasarkan grafik 1.3 diatas terlihat laba Bank BNI Syariahdan BCA syariah mengalami peningkatan disetiap tahunnya sedangkan beberapa perbankan syariah seperti: BRI syariah, Bukopin Syariah, BJB syariah dan Bank Muamalat terlihat mengalami peningkatan dan penurunan. Dari ketiga variabel yang akan diuji terlihat bahwa adanya gap antara teori dengan kenyataan dilapangan. Hal tersebut terlihat ketika dana pihak ketiga dan pendapatan pembiayaan bagi hasil beberapa bank umum syariah mengalami peningkatan setiap tahunnya. Sedangkan pada variabel laba mengalami peningkatan dan penurunan yang cukup signifikan disetiap tahunnya. Perolehan laba perbankan syariah dari tahun 2012-2016 
cenderung fluktuatif, sehingga perbankan harus melakukan penelitian terhadap pengaruh yang menyebabkan laba fluktuatif.

\section{LANDASAN TEORI \\ Dana Pihak Ketiga}

Menurut Dendawijaya (2009:49) mengungkapkan dana-dana pihak ketiga yang dihimpun dari masyarakat merupakan sumber dana terbesar yang paling diandalkan oleh bank (mencapai 80\%-90\% dari seluruh dana yang dikelola oleh bank). Menurut Peraturan Bank Indonesia No. 10/19/PBI/2008 menjelaskan, dana pihak ketiga untuk selanjutnya disebut DPK adalah kewajiban bank kepada penduduk dalam rupiah dan valuta asing. Umumnya dana yang dihimpun oleh perbankan dari masyarakat akan digunakan untuk pendanaan aktivitas sektor riil melalui penyaluran kredit. Menurut Nur Kurnaliyah (2011:30) mengemukakan bahwa dana pihak ketiga merupakan sumber dana yang berasal dari masyarakat yang terhimpun melalui produk giro wadiah, tabungan mudharabah dan deposito mudharabah. Dana pihak ketiga yang dimiliki bank akan disalurkan ke berbagai jenis pembiayaan. Dari beberapa pengertian diatas, dapat disimpulkan bahwa Dana pihak ketiga adalah sumber dana yang berasal dari masyarakat yang terhimpun melalui produk giro wadiah, tabungan mudharabah dan deposito mudharabah yang digunakan untuk pendanaan aktivitas sektor riil melalui penyaluran kredit

\section{Pembiayaan}

Menurut Veithzal dan Arviyan (2010:681), pembiayaan adalah pendanaan yang diberikan oleh suatu pihak kepada pihak lain untuk mendukung investasi yang sudah direncanakan, baik dilakukan sendiri maupun lembaga. Menurut Kasmir (2008:96) mengemukakan bahwa Pembiayaan adalah penyediaan uang atau tagihan yang dipersamakan dengan itu, berdasarkan persetujuan atau kesepakatan antara Bank dengan pihak lain yang mewajibkan pihak yang dibiayai untuk mengembalikan uang atau tagihan tersebut setelah jangka waktu tertentu dengan imbalan atau bagi hasil. Menurut Danupranata (2013:103) mengemukakan bahwa pembiayaan merupakan salah satu tugas pokok bank, yaitu memberikan fasilitas penyediaan dana untuk memenuhi kebutuhan pihak-pihak yang tergolong sebagai pihak yang mengalami kekurangan dana. Dari beberapa pengertian diatas, dapat disimpulkan bahwa pembiayaan dapat diartikan sebagai fasilitas yang berhubungan dengan biaya melalui penyediaan uang atau tagihan berdasarkan persetujuan atau kesepakatan antara Bank dengan pihak lain.

a. Jenis-Jenis Pembiayaan

Menurut Muhammad (2011;91), Manajemen Bank Syariah. Penyaluran dananya pada nasabah, secara garis besar produk pembiayaan syariah terbagi dalam empat kategori yang dibedakan berdasarkan tujuan penggunaanya yaitu:

i. Pembiayaan dengan prinsip jual beli (Ba'i)

Prinsip jual beli dilaksanakan sehubungan dengan adanya perpindahan kepemilikan barang atau benda (Transfer Of Property) Tingkat keuntungan ditentukan didepan dan menjadi bagian harga atas barang yang dijual.

ii. Pembiayaan dengan prinsip sewa (Ijarah)

Pengertian pemberian sewa menyewa dapat didefenisikan sebagai transaksi terhadap penggunaan manfaat suatu barang dan jasa dengan pemberian imbalan. Apabila obyek pemanfaatannya berupa barang, maka imbalannya disebut dengan sewa, sedangkan bila obyeknya berupa tenaga kerja maka imbalannya disebut upah Pada dasarnya ijarah didefinisikan sebagai hak untuk memanfaatkan barang atau jasa dengan membayar imbalan tertentu. 
iii. Pembiayaan dengan Prinsip Bagi Hasil

Pembiayaan dengan prinsip bagi hasil dapat di definisikan aturan perjanjian berdasarkan hukum islam antara Bank dan pihak lain untuk pembiayaan kegiatan usaha, atau kegiatan lainnya yang dinyatakan sesuai dengan syariah.

b. Pembiayaan Bagi Hasil

Menurut Antonio (2009:90) secara umum, prinsip bagi hasil dalam perbankan syariah dapat dilakukan empat akad, yaitu mudharabah, musyarakah, muzara'ah, dan musaqah. Namun demikian, prinsip yang di terapkan di Indonesia ialah musyarakah dan mudharabah.Pembiayaan Musyarakah Menurut Karim (2010:102) menyatakan bahwa musyarakah merupakan semua bentuk usaha yang melibatkan dua pihak atau lebih di mana mereka secara bersama-sama memadukan seluruh bentuk sumber daya baik yang berwujud maupun tidak berwujud. Keuntungan dan kerugian ditanggung bersama sesuai dengan proporsi yang telah ditetapkan sebelumnya.

\section{Dasar Hukum Musyarakah}

\section{Al-Quran}

“... maka mereka berserikat pada sepertiga....”(Q.S. An-Nisa:12)

"Dan, sesungguhnya kebanyakan dari orang-orang yang berserikat itu sebagian mereka berbuat zalim kepada sebagian yang lain, kecuali orang yang beriman dan mengerjakan amal saleh." (Q.S. Sad: 24).

"Dan sesungguhnya kebanyakan dari orang- orang yang berserikat itu sebagian dari mereka berbuat dzalim kepada sebagian yang lain, kecuali orang yang beriman dan mengerjakan amal saleh dan amat sedikitlah mereka ini"'(QS. Shaad (38):24).

\section{Al-Hadist

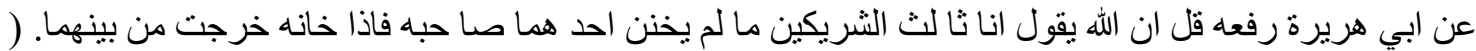

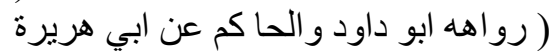

Dari abu hurairah Rasulullah saw bersabda, sesungguhnya Allah azza wa jallah berfirman "aku adalah pihak ketiga dari dua orang yang berserikat selama salah satu tidak ada yang menghianati pihak yang lain. Jika salah satu pihak telah berkhianat, Aku keluar dari mereka" (HR Abu Daud).

Hadis riwayat Abu Daud dari Abu Hurairah merupakan dalil lain diperbolehkan nya praktik musyarakah. Hadis ini merupakan hadist Qudsi, dan kedudukannya sahih menurut Hakim. Di Hadis ini menjelaskan bahwa Allah memberikan pernyataan bahwa mereka yang bersekutu dalam sebuah usaha akan mendapat perniagaan dalam arti Allah akan menjaganya selain itu Allah akan memberikan pertolongan namun Allah juga akan melaknat mereka yang mengkhianati perjanjian dan usahanya. Hal ini lantas memperjelas meskipun memiliki ikatan yang bebas namun kita tidak bisa membatalkan sembarangan apa yang sudah menjadi kerjasamanya.

\section{Ijma}

Ibnu Qudamah dalam kitabnya, Al Mughni mengatakan bahwa "Kaum muslimin telah berkonsensus terhadap legitimasi musyarakah secara global walaupun terdapat perbedaan pendapat dari beberapa elemennya". 
Alur Skema Musyarakah

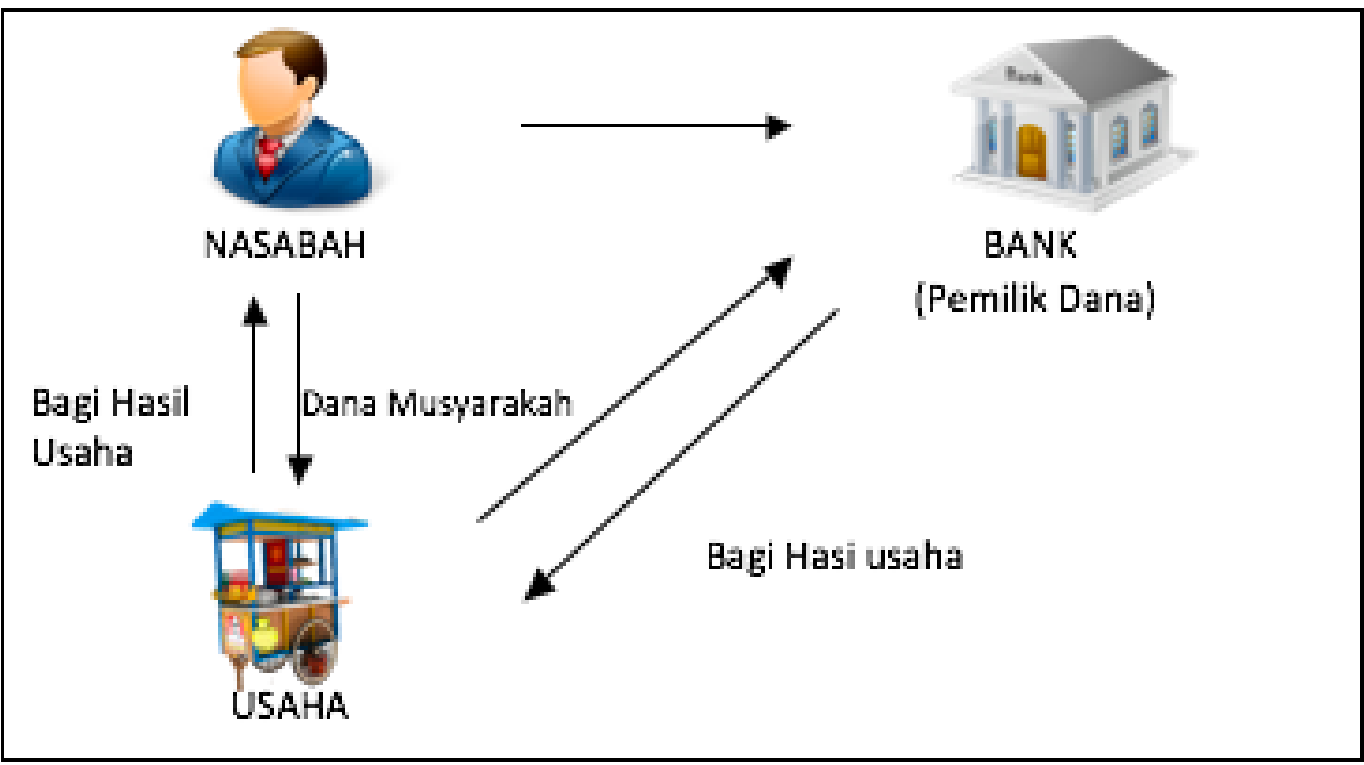

Sumber: www.ojk.go.id

\section{Pengertian Mudharabah}

Menurut Antonio (2011) Mudharabah adalah akad kerja sama usaha antara dua pihak dimana pihak pertama (shabib al-mal) menyediakan seluruh modal, sedangkan pihak lain menjadi pengelola dan keuntungan usaha secara dibagi menurut kesepakatan yang dituangkan dalam kontrak, sedangkan apabila rugi ditanggung oleh pemilik modal selama kerugian itu bukan akibat kelalaian si pengelola.

\section{Dasar Hukum Mudharabah}

Dalil Qur'an

"Sesungguhnya Tuhanmu mengetahui bahwasanya kamu berdiri (sembahyang) kurang dari dua pertiga malam, atau seperdua malam atau sepertiganya dan (demikian pula) segolongan dari orang-orang yang bersama kamu. dan Allah menetapkan ukuran malam dan siang. Allah mengetahui bahwa kamu sekali-kali tidak dapat menentukan batas-batas waktuwaktu itu, Maka Dia memberi keringanan kepadamu, karena itu bacalah apa yang mudah (bagimu) dari Al Quran. Dia mengetahui bahwa akan ada di antara kamu orang-orang yang sakit dan orang-orang yang berjalan di muka bumi mencari sebagian karunia Allah; dan orang-orang yang lain lagi berperang di jalan Allah, Maka bacalah apa yang mudah (bagimu) dari Al Quran dan dirikanlah sembahyang, tunaikanlah zakat dan berikanlah pinjaman kepada Allah pinjaman yang baik. dan kebaikan apa saja yang kamu perbuat untuk dirimu niscaya kamu memperoleh (balasan)nya di sisi Allah sebagai Balasan yang paling baik dan yang paling besar pahalanya. dan mohonlah ampunan kepada Allah; Sesungguhnya Allah Maha Pengampun lagi Maha Penyayang". (Al-Muzzammil [73]: 20). Kata yang menjadi wajhuddilalah atau argument dari ayat di atas adalah yadhribun yang sama dengan akar kata mudharabah yang berarti melakukan suatu perjalanan usaha.

"Tidak ada dosa bagimu untuk mencari karunia (rezki hasil perniagaan) dari Tuhanmu. Maka apabila kamu telah bertolak dari 'Arafat (selesai wuquf), berdzikirlah kepada Allah di Masy'aril Haram dan berdzikirlah (dengan menyebut) Allah sebagaimana yang ditunjukkan-Nya kepadamu; dan Sesungguhnya kamu sebelum itu benar-benar termasuk orang-orang yang sesat”. [Al-Baqarah (2): 198]

\section{Dalil Hadist}




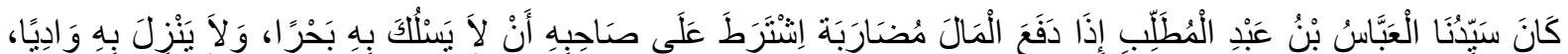

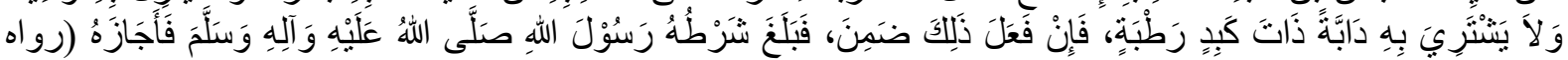
(الطبر اني فى الأوسط عن ابن عباس (روان.

"Adalah Abbas bin Abdul Muththalib, apabila ia menyerahkan sejumlah harta dalam investasi mudharabah, maka ia membuat syarat kepada mudharib, agar harta itu tidak dibawa melewati lautan, tidak menuruni lembah dan tidak dibelikan kepada binatang, Jika mudharib melanggar syarat 2 tersebut, maka ia bertanggung jawab menanggung risiko. Syarat-syarat yang diajukan Abbas tersebut sampai kepada Rasulullah Saw, lalu Rasul membenarkannya".(HR ath_Thabrani). Hadist ini menjelaskan praktek mudharabah muqayyadah.

ثلاثة فيهن البركة : المقارضة والبيع الى اجل وخلط البر بالثعير للبيت لا للبيع(ابن ماجه)

"Tiga macam mendapat barakah: muqaradhah/ mudharabah, jual beli secara tangguh, mencampur gandum dengan tepung untuk keperluan rumah bukan untuk dijual". (HR.Ibnu Majah).

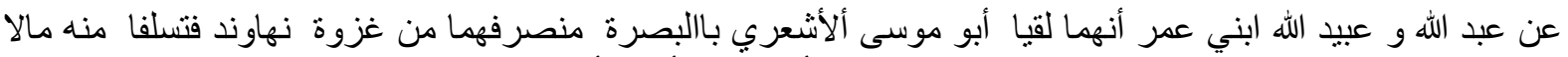

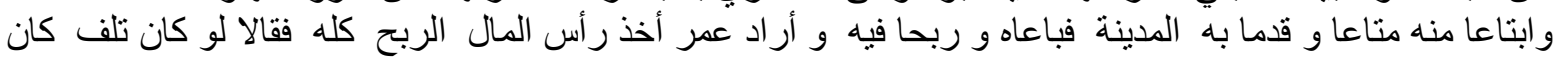

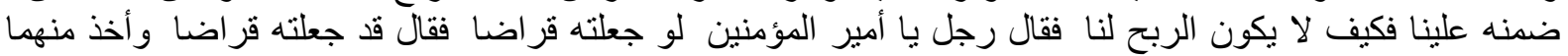
نصف الربح (أخرجه ماللك )

Dari Abdullah dan 'Ubaidullah, keduanya anak Umar, bahwa keduanya bertemu dengan Abu Musa Al-Asy'ary di Basrah, setelah pulang dari perang Nahawand. Keduanya menerima harta dari Abu Musa untuk dibawa ke Madinah (ibu kota). Di perjalanan keduanya membeli harta benda perhiasan, lalu menjualnya di Madinah, sehingga keduanya mendapat keuntungan. Umar memutuskan untuk mengambil modal dan keuntungan semuanya. Tetapi kedua anaknya berkata,"Jika harta itu binasa, bukankah kami yang bertanggung jawab menggantinya. Bagaimana mungkin tak ada keuntungan untuk kami?". Maka berkata seseorang kepada Umar,"Wahai Amirul Mukminin, alangkah baiknya jika engkau jadikan harta itu sebagai qiradh". Umar pun menerima usulan itu. Umar berkata,"Aku menjadikannya qiradh". Umar mengambil separoh dari keuntungan (50\% untuk Baitul Mal dan 50\% untuk kedua anaknya).

\section{Alur Skema Mudharabah}




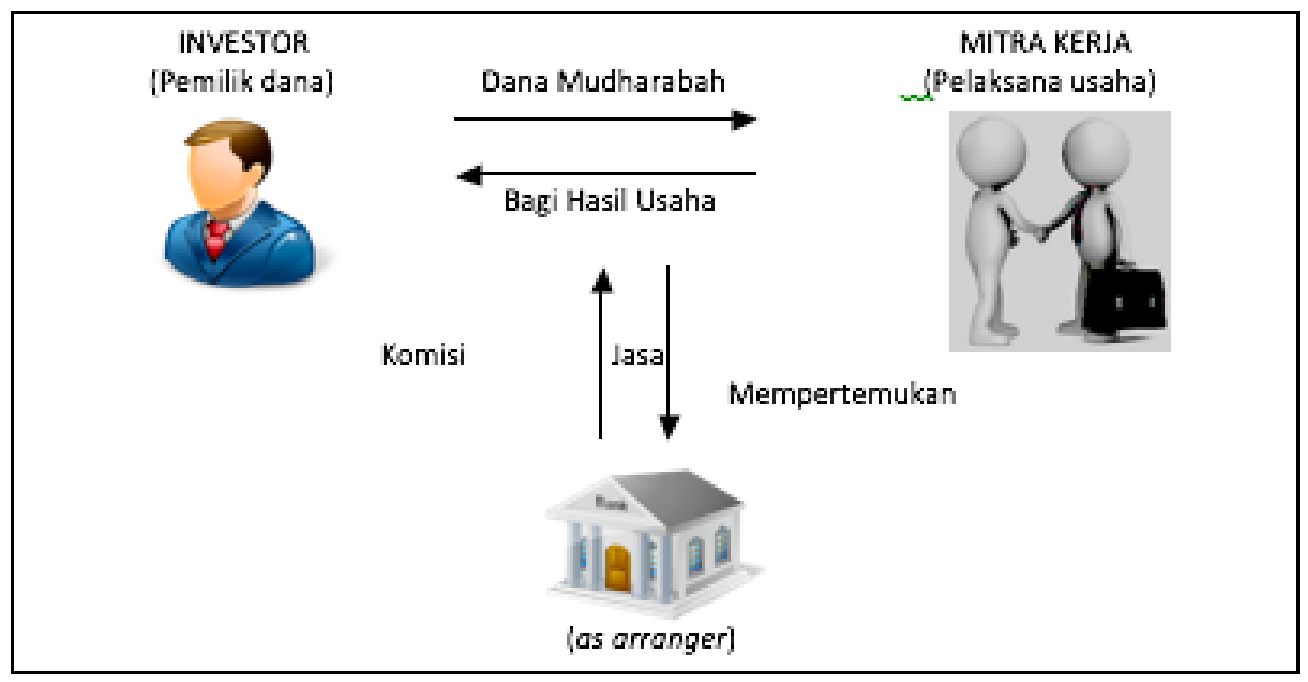

Sumber: www.ojk.go.id

\section{Kerangka Pemikiran}

Kerangka pemikiran yang dapat dikembangkan dalam penelitian ini adalah sebagai berikut : Akuntansi adalah seni dalam melakukan pencatatan, penggolongan, dan pengikhtisaran, yang mana hasil akhirnya tercipta sebuah informasi seluruh aktivitas keuangan perusahaan. Tujuan akuntansi yang digambarkan dalam laporan keuangan adalah untuk memberikan informasi yang bermanfaat untuk pengambilan keputusan para pemakai. (Ismail, 2010:2). Akuntansi Syariah adalah akuntansi yang mempunyai tiga komponen prinsip yaitu prinsip pertanggung jawaban (Accountability), prinsip keadilan dan prinsip kebenaran yang berdasarkan pada hukum syariah dan bersifat universal. (Muhammad, 2012:11). Dana pihak ketiga merupakan sumber dana yang berasal dari masyarakat yang terhimpun melalui produk giro wadiah, tabungan mudharabah dan deposito mudharabah. Dana pihak ketiga yang dimiliki bank akan disalurkan ke berbagai jenis pembiayaan. (Nur Kurnaliyah, 2011:30). Prinsip bagi hasil dalam perbankan syariah dapat dilakukan empat akad, yaitu mudharabah, musyarakah, muzara'ah, dan musaqah. Namun demikian, prinsip yang di terapkan di Indonesia ialah musyarakah dan mudharabah. (Antonio,2009:90)

\section{METODOLOGI PENELITIAN}

Menurut Sugiono (2013:147) menjelaskan bahwa metode deskriptif adalah metode yang digunakan untuk menganalisis data dengan cara mendeskriftifkan atau menggambarkan data yang telah terkumpul yang berlaku untuk umum atau generalisasi. Penelitian ini menggunakan metode deskriptif kuantitatif dalam melakukan penelitian pengaruh dana pihak ketiga dan pendapatan pembiayaan bagi hasil terhadap laba. Variabel Penelitian adalah segala sesuatu yang berbentuk apa saja yang ditetapkan oleh peneliti untuk dipelajari sehingga diperoleh informasi tentang hal tersebut ditarik kesimpulannya, (Sugiyono, 2013:38)

Penelitian ini berfokus pada "Pengaruh Dana Pihak ketiga dan Pendapatan Pembiayaan Bagi Hasil terhadap Laba Pada Bank Umum Syariah ndi Indonesia Periode 2012-2017". Definisi operasional adalah Pengaruh Dana Pihak Ketiga dan Pendapatan pembiayaan Bagi Hasil terhadap Laba sebagai alat bantu pihak manajemen Perbankan di dalam menentukan pengaruh atas dana pihak ketiga serta pendapatan pembiayaan bagi hasil terhadap laba yang dihasilkan. Sehinga perusahaan dapat menentukan keputusan yang akan diambil dalam menghadapi permasalahan laba yang dicapai pada setiap periodenya. Berikut ditampilkan Jurnal Akuntansi : Kajian Ilmiah Akuntansi 
Instrumen Penelitian pada Penelitian “ Pengaruh Dana Pihak Ketiga dan Pendapatan Pembiayaan Bagi Hasil terhadap Laba Pada Bank Umum Syariah di Indonesia Periode 20122017" sebagai berikut :

\section{Tabel 1}

Instrumen Penelitian

\begin{tabular}{|c|c|c|}
\hline Variabel & Dimensi & Indikator \\
\hline Dana Pihak Ketiga (X1) & $\begin{array}{l}\text { Dana pihak ketiga merupakan } \\
\text { sumber dana yang berasal dari } \\
\text { masyarakat yang terhimpun } \\
\text { melalui produk giro wadiah, } \\
\text { tabungan mudharabah dan } \\
\text { deposito mudharabah. Dana } \\
\text { pihak ketiga yang dimiliki } \\
\text { bank akan disalurkan ke } \\
\text { berbagai jenis pembiayaan. } \\
\text { Nur Kurnaliyah (2011:30) }\end{array}$ & $\begin{array}{l}\text { Dana Pihak Ketiga = Giro + } \\
\text { Tabungan + Deposito. } \\
\text { Nur Kurnaliyah }(2011: 30)\end{array}$ \\
\hline $\begin{array}{l}\text { Pendapatan Pembiayaan } \\
\text { Bagi Hasil (X2) }\end{array}$ & $\begin{array}{l}\text { Secara umum, prinsip bagi } \\
\text { hasil dalam perbankan syariah } \\
\text { dapat dilakukan empat akad, } \\
\text { yaitu mudharabah, } \\
\text { musyarakah, muzara'ah, dan } \\
\text { musaqah. Namun demikian, } \\
\text { prinsip yang di terapkan di } \\
\text { Indonesia ialah musyarakah } \\
\text { dan mudharabah. Antonio } \\
\text { (2009:90) }\end{array}$ & $\begin{array}{l}\text { Pembiayaan Bagi Hasil = } \\
\text { Pembiayaan Musyarakah + } \\
\text { Pembiayaan Mudharabah } \\
\text { Antonio (2009:90) }\end{array}$ \\
\hline Laba (Y) & $\begin{array}{l}\text { Laba merupakan ukuran } \\
\text { keseluruhan prestasi } \\
\text { perusahaan, yang didefiniskan } \\
\text { sebagai berikut : Laba = } \\
\text { Penjualan - Biaya. } \\
\text { Mahmud M. Hanafi (2010:32). }\end{array}$ & $\begin{array}{l}\text { Laba = Penjualan - Biaya } \\
\text { Mahmud M. Hanafi (2010:32). }\end{array}$ \\
\hline
\end{tabular}

Sumber : Data yang diolah, 2018

\section{HASIL DAN PEMBAHASAN}

Penelitian ini menggunakan metode Purposive Sampling, data yang digunakan dalam penelitian ini adalah balanced pooled data, dimana setiap unit analisis memiliki jumlah observasi yang sama pada setiap waktu/periode (Gujarati, 2003:630), sehingga jumlah pengamatan yang digunakan sebanyak 36 pengamatan. Analisis data menggunakan metode multiple regression analysis (analisis regresi berganda) dan Korelasi berganda. Uji Statistik Deskriptif Deskripsi data penelitian memberikan gambaran umum mengenai variabel penelitian yang terdiri dari variabel dana pihak ketiga, pendapatan pembiayaan bagi hasil dan laba.

Berikut data dana pihak ketiga , pendapatan pembiayaan bagi hasil dan laba pada bank umum syariah periode 2012-2017:

\section{Tabel 2}


Data dana pihak ketiga , pendapatan pembiayaan bagi hasil dan laba pada bank umum syariah periode 2012-2017

\begin{tabular}{|c|c|c|c|}
\hline TAHUN & $\begin{array}{c}\text { DANA PIHAK } \\
\text { KETIGA } \\
\end{array}$ & $\begin{array}{l}\text { PENDAPATAN } \\
\text { PEMBIAYAAN }\end{array}$ & LABA \\
\hline \multicolumn{4}{|c|}{ 1. BANK BNI SYARIAH } \\
\hline 2012 & 8.980 .000 & 122.777 & 101.892 \\
\hline 2013 & 11.420 .000 & 172.308 & 117.462 \\
\hline 2014 & 16.250 .000 & 235.469 & 163.251 \\
\hline 2015 & 19.320 .000 & 295.164 & 228.530 \\
\hline 2016 & 24.230 .000 & 406.598 & 277.380 \\
\hline 2017 & 29.380 .000 & 464.890 & 306.680 \\
\hline \multicolumn{4}{|c|}{ 2. BANK BCA SYARIAH } \\
\hline 2012 & 1.261 .800 & 31.705 & 8.400 \\
\hline 2013 & 1.703 .000 & 64.015 & 12.700 \\
\hline 2014 & 2.338 .700 & 88.197 & 12.900 \\
\hline 2015 & 3.255 .200 & 145.410 & 23.400 \\
\hline 2016 & 3.842 .300 & 153.010 & 36.800 \\
\hline 2017 & 4.736 .400 & 190.500 & 47.900 \\
\hline \multicolumn{4}{|c|}{ 3. BANK BRI SYARIAH } \\
\hline 2012 & 11.948 .888 & 241.946 & 101.888 \\
\hline 2013 & 14.349 .712 & 400.351 & 129.564 \\
\hline 2014 & 16.940 .990 & 501.604 & 65.770 \\
\hline 2015 & 20.123 .658 & 642.005 & 122.637 \\
\hline 2016 & 22.000 .000 & 693.611 & 170.209 \\
\hline 2017 & 25.360 .000 & 670.205 & 101.910 \\
\hline \multicolumn{4}{|c|}{ 4. BANK BUKOPIN SYARIAH } \\
\hline 2012 & 2.850 .784 & 88.521 & 17.298 \\
\hline 2013 & 3.272 .263 & 114.767 & 19.548 \\
\hline 2014 & 3.994 .957 & 170.222 & 8.499 \\
\hline 2015 & 4.756 .303 & 206.803 & 27.778 \\
\hline 2016 & 5.442 .609 & 294.598 & 32.710 \\
\hline 2017 & 10.071 .915 & 137.012 & 126.700 \\
\hline \multicolumn{4}{|c|}{ 5. BANK JABAR BANTEN SYARIAH } \\
\hline 2012 & 3.067 .423 & 84.763 & $(22.824)$ \\
\hline 2013 & 3.356 .143 & 156.129 & 28.316 \\
\hline 2014 & 4.707 .098 & 143.904 & 21.702 \\
\hline 2015 & 4.563 .559 & 135.615 & 7.279 \\
\hline 2016 & 5.118 .972 & 105.674 & $(414.714)$ \\
\hline 2017 & 5.600 .000 & 93.296 & $(383.423)$ \\
\hline \multicolumn{4}{|c|}{ 6. BANK MUAMALAT } \\
\hline 2012 & 34.904 .000 & 1.236 .346 & 46.000 \\
\hline 2013 & 41.970 .000 & 1.938 .358 & 165.000 \\
\hline 2014 & 51.206 .000 & 2.299 .682 & 59.000 \\
\hline 2015 & 45.078 .000 & 2.165 .716 & 74.000 \\
\hline
\end{tabular}




\section{Tabel 3}

Descriptive Statistics

\begin{tabular}{lrrrrrc}
\hline & & & & & & Std. \\
& N & \multicolumn{2}{c}{ Minimum Maximum } & \multicolumn{2}{c}{ Mean } & Deviation \\
& Statistic & Statistic & Statistic & Statistic & Std. Error & Statistic \\
\hline Dana Pihak Ketiga & 36 & 1.2606 & 5.1207 & 1.550007 & 2.5112806 & 1.5067707 \\
Pendapatan Pembiayaan & 36 & 31705.00 & 2.3006 & 4.839105 & 1.0202405 & 6.1214405 \\
Bagi Hasil & 36 & -4.1505 & 3.0705 & 5.414304 & 2.2608304 & 1.3565005 \\
Laba & 36 & & & & & \\
Valid N (listwise) & 36 & & & & & \\
\hline
\end{tabular}

Sumber : Data diolah, 2018

Berdasarkan tabel dari jumlah sampel 6 perbankan syariah dapat dilihat nilai terendah, tertinggi,standar deviasi dan rata-rata dalam periode 2012-2017. Variabel dana pihak ketiga didapat nilai terendah yaitu 1,2606. Nilai tertinggi sebesar 5,1207, nilai rata-rata dana pihak ketiga 1,550007 dengan standar deviasi 1,5067707. Pada variabel pendapatan pembiayaan bagi hasil diperoleh nilai terendah 31705,00 Nilai tertinggi sebesar 2,3006, nilai rata-rata pendapatan pembiayaan bagi hasil 4,839105 dengan standar deviasi 6.1214405. Kemudian pada variabel laba nilai terendah yaitu $-4,1505$. Nilai tertinggi sebesar 3,0705, nilai rata-rata laba 5,414304 dengan standar deviasi 1,3565005.

\section{Hasil Pengujian Hipotesis}

Tabel 4
Hasil Analisis Regresi Dana Pihak Ketiga, Pendapatan Pembiayaan Bagi Hasil dan Laba Pada Bank Umum Syariah periode Tahun 2012-2017

\section{Coefficients $^{\mathrm{a}}$}

\begin{tabular}{|c|c|c|c|c|c|c|}
\hline \multirow[b]{2}{*}{ Model } & & \multicolumn{2}{|c|}{$\begin{array}{l}\text { Unstandardized } \\
\text { Coefficients }\end{array}$} & \multirow{2}{*}{$\begin{array}{c}\text { Standardized } \\
\text { Coefficients } \\
\text { Beta } \\
\end{array}$} & \multirow[b]{2}{*}{$\mathrm{T}$} & \multirow[b]{2}{*}{ Sig. } \\
\hline & & $\mathrm{B}$ & Std. Error & & & \\
\hline \multirow[t]{3}{*}{1} & (Constant) & -5572.507 & 31178.326 & & -.179 & .859 \\
\hline & Dana Pihak Ketiga & .008 & .003 & .841 & 2.314 & .027 \\
\hline & $\begin{array}{l}\text { Pendapatan Pembiayaan } \\
\text { Bagi Hasil }\end{array}$ & -.119 & .081 & -.537 & -1.479 & .149 \\
\hline
\end{tabular}

a. Dependent Variable: Laba 
Berdasarkan hasil olahan spss diatas didapat persamaan regresinya adalah $\mathrm{Y}=$ $5572,507+0,008$ DPK - 0,119 PPBH. Variabel dana pihak ketiga memiliki nilai t hitung 2,314 dengan tingkat signifikansi 0,027 lebih kecil dari taraf signifikansi 0,05 (5\%) dan memiliki pengaruh yang positif. Hal ini menunjukkan bahwa dana pihak ketiga memiliki pengaruh terhadap laba dan tanda positif pada koefisien regresi menunjukkan hubungan yang searah, dimana ketika dana pihak ketiga meningkat maka laba juga mengalami peingkatan begitu juga sebaliknya yaitu ketika dana pihak ketiga mengalami penurunan maka laba juga akan ikut turun.

Variabel pendapatan pembiayaan bagi hasil memiliki t hitung $-1,479$ dengan signifikansi 0,149 lebih kecil dari taraf signifikansi 0,05 (5\%) dan memiliki pengaruh yang negatif. Hal ini menunjukkan bahwa pendapatan pembiayaan bagi hasil memiliki pengaruh terhadap labadan tanda negatif pada koefisien regresi menunjukkan hubungan yang berbalik arah, dimana ketika pendapatan pembiayaan bagi hasil meningkat maka laba akan menurun, begitu juga ketika pendapatan pembiayaan bagi hasil menurun maka laba akan meningkat. Hubungan dana pihak ketiga terhadap laba Hasil olah data SPSS mengenai hubungan dana pihak ketiga terhadap laba sebagai berikut :

\section{Tabel 5}

Hubungan Dana Pihak Ketiga terhadap Laba Correlations

\begin{tabular}{llrr}
\hline & & Dana Pihak Ketiga & Laba \\
\hline Dana Pihak & Pearson Correlation & 1 & $.357^{*}$ \\
Ketiga & Sig. (2-tailed) & & .033 \\
& $\mathrm{~N}$ & 36 & 36 \\
Laba & Pearson Correlation & $.357^{*}$ & 1 \\
& Sig. (2-tailed) & .033 & 36 \\
& $\mathrm{~N}$ & 36 & 36 \\
\hline
\end{tabular}

*. Correlation is significant at the 0.05 level (2-tailed).

Berdasarkan tabel 5 dapat dilihat bahwa hubungan dana pihak ketiga terhadap laba diperoleh 0,357 . Dengan demikian kekuatan hubungan antara dana pihak ketiga terhadap laba berada pada tingkat hubungan tidak kuat karena berada pada range 0,20-0,39.

\section{Hubungan Pendapatan Pembiayaan bagi Hasil Terhadap Laba}

Hasil olah data SPSS mengenai hubungan pendapatan pembiayaan bagi hasil terhadap laba sebagai berikut :

Tabel 6

Hubungan Pendapatan Pembiayaan Bagi hasil Terhadap Laba

\section{Correlations}

Laba Pendapatan Pembiayaan Bagi Hasil 


\begin{tabular}{llrr}
\hline Laba & Pearson & 1 & .220 \\
& Correlation & & .196 \\
& Sig. (2-tailed) & & 36 \\
& $\mathrm{~N}$ & 36 & 1 \\
Pendapatan Pembiayaan & Pearson & .220 & \\
Bagi Hasil & Correlation & .196 & 36 \\
& Sig. (2-tailed) & 36 & \\
& $\mathrm{~N}$ &
\end{tabular}

Berdasarkan tabel 6 dapat dilihat bahwa hubungan pendapatan pembiayaan bagi hasil terhadap laba diperoleh 0,220. Dengan demikian kekuatan hubungan antara dana pihak ketiga terhadap laba berada pada tingkat hubungan tidak kuat karena berada pada range 0,20 0,39 .

\section{Uji Simultan (Uji F)}

Hasil olah data SPSS mengenai hubungan secara simultan dana pihak ketiga dan pendapatan pembiayaan bagi hasil terhadap laba sebagai berikut :

\section{Tabel 7}

\section{Hubungan secara simultan dana pihak ketiga dan pendapatan pembiayaan bagi} hasil terhadap laba

ANOVA ${ }^{b}$

\begin{tabular}{llrrrrr}
\hline Model & Sum of Squares & df & Mean Square & F & \multicolumn{1}{c}{ Sig. } \\
\hline 1 & Regression & $1.168 \mathrm{E} 11$ & 2 & $5.842 \mathrm{E} 10$ & 3.657 & $.037^{\mathrm{a}}$ \\
& Residual & $5.272 \mathrm{E} 11$ & 33 & $1.598 \mathrm{E} 10$ & & \\
& Total & $6.440 \mathrm{E} 11$ & 35 & & & \\
\hline
\end{tabular}

a. Predictors: (Constant), Pendapatan Pembiayaan Bagi Hasil, Dana Pihak Ketiga

b. Dependent Variable: Laba

Berdasarkan Tabel 7 diatas terlihat nilai $\mathrm{F}$ sebesar 3,657 dengan signifikansi sebesar 0,037. Nilai signifikansi tersebut lebih kecil dari 0,05. Dengan demikian dapat disimpulkan bahwa antara dana pihak ketiga dan pendapatan pembiayaan bagi hasil berpengaruh secara bersama-sama terhadap laba pada bank umum syariah sehingga hipotesis dapat diterima.

\section{SARAN DAN KESIMPULAN}

Hubungan dana pihak ketiga terhadap laba diperoleh 0,357 Dengan demikian kekuatan hubungan antara dana pihak ketiga terhadap laba berada pada tingkat hubungan tidak kuat karena berada pada range 0,20 - 0,39. Hubungan pendapatan pembiayaan bagi hasil terhadap laba diperoleh 0,220 atau sebesar. Dengan demikian kekuatan hubungan antara dana pihak ketiga terhadap laba berada pada tingkat hubungan tidak kuat karena berada pada range 0,20-0,39. Nilai F sebesar 3,657 dengan signifikansi sebesar 0,037. Dengan demikian hubungan secara simultan memiliki hubungan yang signifikan karena nilai signifikansi kurang dari 0,05. Penelitian ini menggunakan periode waktu 6 tahun yaitu periode 20122017, untuk itu dalam penelitian mendatang bisa digunakan periode waktu yang lebih lana Jurnal Akuntansi : Kajian IImiah Akuntansi 
sehingga dapat lebih menggambarkan faktor-faktor yang mempengaruhi laba. Diharapkan pada penelitian selanjutnya untuk menambahkan beberapa variabel lainnya yang diduga mempengaruhi laba seperti net operating margin, return on asset dan capital adequacy ratio. Penelitian ini hanya dilakukan pada perbankan syariah yang masuk dalam golongan bank umum syariah, untuk penelitian selanjutnya diharapkan dapat menggunakan perbankaperbankan selain perbankan yang berbasis syariah, karena memungkinkan adanya hasil lain dan kesimpulan yang berbeda pada saat melakukan penelitian selanjutnya.

\section{DAFTAR PUSTAKA}

Adiwarman A.Karim. 2010. Bank Islam: Analisis Fiqih dan Keuangan. Jakarta:Raja Grafindo Persada.

Andi Supangat. 2007. Statistika dalam Kajian Deskriftif, Inferensi dan Nonparametrik. Edisi Pertama. Jakarta: Kencana Prenada Media Group.

Antonio , Muhammad Syafi'i. 2011. Bank Syariah: Dari Teori Ke Praktik. Depok: Gema Instansi.

Antonio, muhammad Syafi'i. 2001. Bank Syariah Dari Teori ke Praktik. Gema Insani Press. Jakarta.

Antonio, Muhammad Syafii. 2011. Bank Syariah : Dari Teori ke Praktek. Jakarta. Gema Insani Press bekerjasama dengan yayasan Tazkia Cendekia.

Antonio, Muhammad. 2009. Bank Syariah : dari Teori ke Praktik. Jakarta: Gema Insani Press Arifin Zainul. (2009). Dasar-Dasar Manajemen Bank Syariah. Tangerang: Azkia

Bank Indonesia. (2008). Statistik Perbankan Indonesia. Jakarta: Bank Indonesia

Danupranata, Gita, 2013, Manajemen Perbankan Syariah, Salemba Empat, Jakarta.

Dendawijaya, Lukman. (2009). Manajemen Perbankan. Jakarta: Ghalia Indonesia

Ghozali, Imam. 2011. Aplikasi Analisis Multivariate Dengan Program IBM SPSS 19 (edisi kelima). Semarang : Universitas Diponegoro.

Hanafi, Mahmud M. (2010) Manajemen Keuangan. Cetakan ke lima. Yogyakarta: BPFE. Harahap Sofyan Syafri (2011), Teori Akuntansi Edisi Revisi 2011. Jakarta: Rajawali Pers

Harahap, Sofyan Syafri. 2009. Analisis Kritis Atas Laporan Keuangan. Jakarta : RajaGrafindo Persada.

Ikatan Akuntansi Indonesia, 2002, Standar Akuntansi Keuangan,

Ismail. (2010). Manajemen Perbankan : Dari Teori Menuju Aplikasi. Jakarta: Kencana.

Ismail.2010. Akuntansi Bank. Jakarta : Penerbit Kencana.

Kasmir. 2008.Bank dan Lembaga Keuangan Lainnya.Edisi Revisi 2008. Jakarta: PT. RAJAGRAFINDO PERSADA.

Kieso, Donald. E., Jerry J. Weygandt, dan Terry D. Warfield. 2010.Intermediate Accounting IFRS Edition. Edisi 1. Volume 1. John Wiley \& Sons.

Kurnaliyah, Nur. 2011. "Pemodelan pembiayaan mudharabah perbankan syariah dengan metode system dinamika". Universitas Islam Negeri Jakarta, Jakarta.

Moh Nazir. 2003. Metode Penelitian. Jakarta: Ghalia Indonesia

Mulyadi, 2001, 'Sistem Akuntansi', Edisi Ketiga, Jakarta: Salemba Empat

Pura, Rahman, 2012. Pengantar Akuntansi 1. Penerbit Erlangga. Jakarta.

Rivai, Veithzal dan Arviyan Arifin. Islamic Banking: Sebuah Teori, Konsep, dan Aplikasi. Jakarta: Bumi Aksara. 2010.

Salemba Empat, Jakarta.

Sony Warono bin Hardono, Ratna Candrasari, Irene Natalia. 2013. Akuntansi Pengantar 1. AB Publisher : Yogyakarta.

Sri Nurhayati Dan Wasilah. 2013. Akuntansi Syariah Di Indonesia Edisi 3. Jakarta : Salemba Empat. 
Sugiyono, 2015. Metode Penelitian Pendidikan. Bandung : Alfabeta.

Suwardjono. 2008. Teori Akuntansi Perekayasaan Pelaporan Keuangan. Yogyakarta : BPFE.

Umi Narimawati dkk.2010. Penulisan Karya Ilmiah, Panduan Awal Menyusun Skripsi dan Tugas Akhir. Jakarta: Genesis.

Umi, Narimawati., Sri Dewi, Anggadini., Linna, Ismawati. (2011), Penulisan Karya Ilmiah, Edisi Pertama, Genesis. Pondok Gede, Bekasi.

Wiroso, 2011. Akuntansi Transaksi Syariah. Jakarta : Ikatan Akuntansi Indonesia

Windi Widia. 2012. Pengaruh dana pihak ketiga terhadap pembiayaan dan implikasinya terhadap laba Bank Syariah di Indonesia. Elib.unikom.ac.id

Luh Puspawati, Drs Wayan Cipta, M.M., Ni Nyoman Yuliantini, S.E.,M.M. 2016. Pengaruh dana pihak ketiga dan jumlah penyaluran kredit terhadap laba. Ejurnal.undiksha.ac.id

Cut Marliana TA dan Meutia Fitri, S.E, M.M,Ak. 2016. Pengaruh biaya operasional, dana pihak ketiga dan non performing finance terhadap pertumbuhan laba pada Perbankan Syariah di Indonesia. Jim.unsyiah.ac.id

Agustina Dwi Cahyaningrum. 2016. Pengaruh pembiayaan mudharabah, dana pihak ketiga dan non performing financing pada profitabilitas di Bank Umum Syariah Indonesia 2012-2015. Eprints.iain-surakarta.ac.id

Sapta Lirantia Purnamasari. 2009. Pengaruh pembiayaan mudharabah, pembiayaan musyarakah, dan pembiayaan murabahah terhadap laba pada Bank Syariah periode 2000-2008. Karya-ilmiah.um.ac.id

Sri Anastasya. 2013. The Influence of Third-Party Funds, Car, Npf, and Roa Againts The Financing of a General Sharia-Based Bank in Indonesia, The IBEA. Internasional Confrence on Business, Economic, Bankok. 